\title{
Paenibacillus sabinae sp. nov., a nitrogen-fixing species isolated from the rhizosphere soils of shrubs
}

\author{
Correspondence \\ Sanfeng Chen \\ chensf@cau.edu.cn
}

\author{
Yuchao Ma, ${ }^{1,2}$ Zhiqiang $\mathrm{Xia}_{1}{ }^{3}$ Xuming $\mathrm{Liu}^{3}$ and Sanfeng Chen ${ }^{1,2}$ \\ ${ }^{1}$ National Key Laboratory for Agrobiotechnology, China Agricultural University, Beijing 100094, \\ People's Republic of China \\ ${ }^{2}$ Key Laboratory of Agro-Microbial Resource and Application, China Agricultural University, \\ Beijing 100094, People's Republic of China \\ ${ }^{3}$ College of Biological Sciences, China Agricultural University, Beijing 100094, People's \\ Republic of China
}

\begin{abstract}
Five novel endospore-forming, nitrogen-fixing bacterial strains were isolated from the rhizosphere soils of plants of the species Sabina squamata, Weigela florida and Zanthoxylum simulans. A phylogenetic analysis based on 16S rRNA gene sequences revealed that the five strains formed a distinct cluster within the genus Paenibacillus. These novel strains showed the highest levels (96.2-98.2\%) of $16 \mathrm{~S}$ rRNA gene sequence similarity with Paenibacillus azotofixans. However, the DNA-DNA relatedness between these novel strains and $P$. azotofixans was $12.9-29.5 \%$. The DNA $G+C$ contents of the five strains were found to be 51.9-52.9 mol\%. Phenotypic analyses showed that a significant feature of the novel strains (differentiating them from $P$. azotofixans and other Paenibacillus species) is that all of them were unable to produce acid and gas from various carbohydrates such as glucose, sucrose, lactose and fructose. Anteiso-branched $\mathrm{C}_{15 \text { : }}$ was the major fatty acid present in the novel type strain. On the basis of these data, the five novel strains represent a novel species of the genus Paenibacillus, for which the name Paenibacillus sabinae sp. nov. is proposed. The type strain is $\mathrm{T}^{2} 7^{\top}\left(=\right.$ CCBAU $\left.10202^{\top}=\mathrm{DSM} 17841^{\top}\right)$.
\end{abstract}

The genus Paenibacillus was first proposed by Ash et al. (1993) on the basis of phylogenetic data from 16S rRNA gene sequences. At that time, the genus Paenibacillus encompassed 11 species, including the nitrogen-fixing species Paenibacillus polymyxa (Grau \& Wilson, 1962), Paenibacillus macerans (Witz et al., 1967) and Paenibacillus azotofixans (Seldin et al., 1983, 1984). Since then, continual transfers of Bacillus species to the genus and descriptions of novel Paenibacillus species have increased the number of recognized Paenibacillus species considerably (Tcherpakov et al., 1999; Van der Maarel et al., 2000; Elo et al., 2001). At the time of writing, in addition to the three species mentioned above, the following Paenibacillus species have been described as being nitrogen-fixers (on the basis of showing positive nitrogenase activity with the acetylenereduction method or a PCR-amplified nifH fragment): $P$. peoriae and P. borealis (Elo et al., 2001), P. graminis and P. odorifer (Berge et al., 2002), P. brasilensis (von der Weid et al., 2002), P. wynnii (Rodríguez-Díaz et al., 2005) and P. massiliensis (Ding et al., 2005). Almost all of the

The GenBank/EMBL/DDBJ accession numbers for the 16S rRNA and nifH gene sequences of strains T27 ${ }^{\mathrm{T}}, \mathrm{T} 67, \mathrm{~T} 49, \mathrm{JD} 2$ and G18-7 are DO338444-DO338448 and DO349125-DO349129, respectively. nitrogen-fixing Paenibacillus species described were isolated from the rhizosphere soils or roots of graminaceous plants. Here we describe the isolation and classification of a novel nitrogen-fixing species within the genus Paenibacillus.

The bacterial strains studied here were isolated from the rhizosphere soils of three species of shrubs, namely singleseed savin (Sabina squamata), brocadebeldflower (Weigela florida) and pricklyash (Zanthoxylum simulans). Soil samples were collected and each sample $(1 \mathrm{~g})$ was placed in $9 \mathrm{ml}$ sterile water and stirred for $50 \mathrm{~min}$. Aqueous portions $\left(100 \mu \mathrm{l}\right.$ of the mixture) were heated at $80^{\circ} \mathrm{C}$ for $10 \mathrm{~min}$ and then spread on nitrogen-free medium in triplicate and incubated at $30^{\circ} \mathrm{C}$. The nitrogen-free medium used for the isolation of bacterial strains contained $20 \mathrm{~g}$ sucrose, $0.1 \mathrm{~g} \mathrm{~K}_{2} \mathrm{HPO}_{4}, 0.4 \mathrm{~g} \mathrm{KH}_{2} \mathrm{PO}_{4}, 0.2 \mathrm{~g} \mathrm{MgSO}_{4} .7 \mathrm{H}_{2} \mathrm{O}$, $0.1 \mathrm{~g} \mathrm{NaCl} 0.01 \mathrm{~g} \mathrm{FeCl}_{3}$ and $0.002 \mathrm{~g} \mathrm{Na}_{2} \mathrm{MoO}_{4}$ dissolved in 11 water. After 5 days incubation, strains T27 ${ }^{\mathrm{T}}, \mathrm{T} 49$ and T67 were isolated from the rhizosphere soil of the plant $S$. squamata, strain JD2 was from $W$. florida and strain G18-7 was from $Z$. simulans.

As mentioned above, strains were obtained by screening on nitrogen-free medium. To confirm the nitrogen-fixing capabilities of the five strains, an assay for nitrogenase 
activity and a PCR amplification of the nifH gene were carried out. Two degenerate primers (forward primer 5'-GGCTGCGATCC(CGA)AAGGCCGA(CT)TC(CGA)ACCCG-3' and reverse primer 5'-CTG(GCA)GCCTTGTT(CT)TCGCGGAT(CG)GGCATGGC-3') were used to amplify a $324 \mathrm{bp}$ fragment of the nif $H$ gene from the five strains, as described by Ding et al. (2005). Our results showed that the five strains possess nifH genes; their GenBank accession numbers are indicated after the bacterial names in Fig. 1. The deduced amino acid sequences of the nifH gene products from the five strains were aligned, using CLUSTAL_X software (Thompson et al., 1997) with NifH sequences held in GenBank. A phylogenetic tree was generated using the neighbour-joining method with the software package TREECONW (Van de Peer \& De Wachter, 1994). The phylogenetic analysis based on NifH sequences revealed that the five strains clustered together with Paenibacillus species (Fig. 1). The five novel strains were also tested for nitrogenase activity by using the acetylenereduction assay (Berge et al., 2002). All of the strains were grown in screw-capped tubes with $5 \mathrm{ml}$ liquid RCV mineral medium (Weaver et al., 1975) containing $2 \%$ glucose. After $48 \mathrm{~h}$ incubation at $30^{\circ} \mathrm{C}$, the caps were replaced by silicone stoppers and $1.5 \%$ of the inner atmosphere of the tube was replaced by acetylene; the tubes were incubated under this atmosphere for $2 \mathrm{~h}$ and then analysed for ethylene production by gas chromatography as described by Berge et al. (2002). P. azotofixans, P. polymyxa, P. macerans, $P$. odorifer and $P$. graminis were also tested (as reference strains) for their capacity to fix nitrogen by assaying their nitrogenase activities. As shown in Table 1, all of the novel strains exhibited significant nitrogenase activity. These data suggested that these novel stains were nitrogen-fixers.

Strains belonging to the genus Paenibacillus are usually identified by PCR amplification of a $16 \mathrm{~S}$ rRNA gene fragment with the highly specific forward primer PAEN515F (5'-GCTCGGAGAGTGACGGTACCTGAGA-3') and universal reverse primer 1377R (Shida et al., 1997). An 860 bp
Table 1. Nitrogenase activities of the five novel strains and Paenibacillus species

\begin{tabular}{|c|c|}
\hline \multirow[t]{2}{*}{ Strain } & Activity \\
\hline & nmol $\mathrm{C}_{2} \mathrm{H}_{2}(\mathrm{mg} \text { protein })^{-1}$ \\
\hline P. azotofixans ATCC $35681^{\mathrm{T}}$ & $2256.8 \pm 46.9$ \\
\hline$P$. polymyxa DSM $36^{\mathrm{T}}$ & $3.2 \pm 0.55$ \\
\hline P. macerans ATCC $8244^{\mathrm{T}}$ & $2.48 \pm 0.2$ \\
\hline P. odorifer TOD $45^{\mathrm{T}}$ & $37.62 \pm 18.9$ \\
\hline P. graminis $\mathrm{RSA} 19^{\mathrm{T}}$ & $272.9 \pm 7.9$ \\
\hline $\mathrm{T} 27^{\mathrm{T}}$ & $3885.9 \pm 72.9$ \\
\hline T49 & $2080.4 \pm 7.2$ \\
\hline T67 & $1896.1 \pm 106.5$ \\
\hline JD2 & $2202.2 \pm 81.2$ \\
\hline G18-7 & $2093.8 \pm 224.4$ \\
\hline
\end{tabular}

fragment was PCR-amplified from each of the novel strains when the Paenibacillus-specific primers PAEN515F and 1377R were used in this study. The results suggested that these novel strains were members of the genus Paenibacillus.

An almost-complete 16S rRNA gene sequence was amplified from each of the five novel strains, as described by Yoon et al. (2002), and the PCR products were sequenced; the GenBank accession numbers of the five novel strains are indicated after the bacterial names in Fig. 2. The 16S rRNA gene sequences of the five novel strains were aligned with those of their most closely related species in the genus Paenibacillus by using the CLUSTAL W program (Thompson et al., 1994). A phylogenetic analysis based on 16S rRNA gene sequences revealed that the five strains formed one distinct cluster within the genus Paenibacillus (Fig. 2). The highest levels of $16 \mathrm{~S}$ rRNA gene sequence similarity between the five novel strains T27 ${ }^{\mathrm{T}}, \mathrm{T} 67, \mathrm{~T} 49, \mathrm{JD} 2$ and G18-7 and P. azotofixans were $97.8,97.6,97.2,98.23$ and $96.2 \%$, respectively. The $16 \mathrm{~S}$ rRNA gene sequence similarities among the five novel strains were $98.2-99.1 \%$.

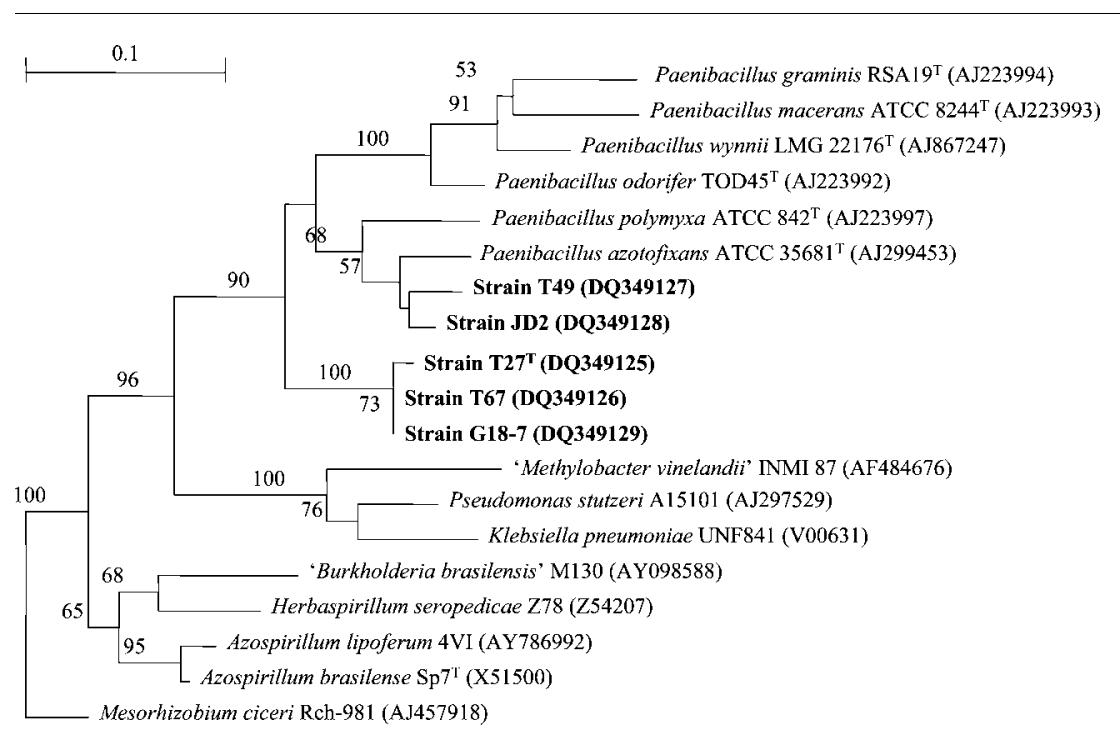

Fig. 1. Phylogenetic tree based on partial $\mathrm{NifH}$ sequences, showing the position of the five novel strains in relation to other bacterial species from the database. Numbers at branching points represent bootstrap values from 1000 replicates; only values greater than $50 \%$ are shown. Bar, 0.1 substitutions per nucleotide position. 


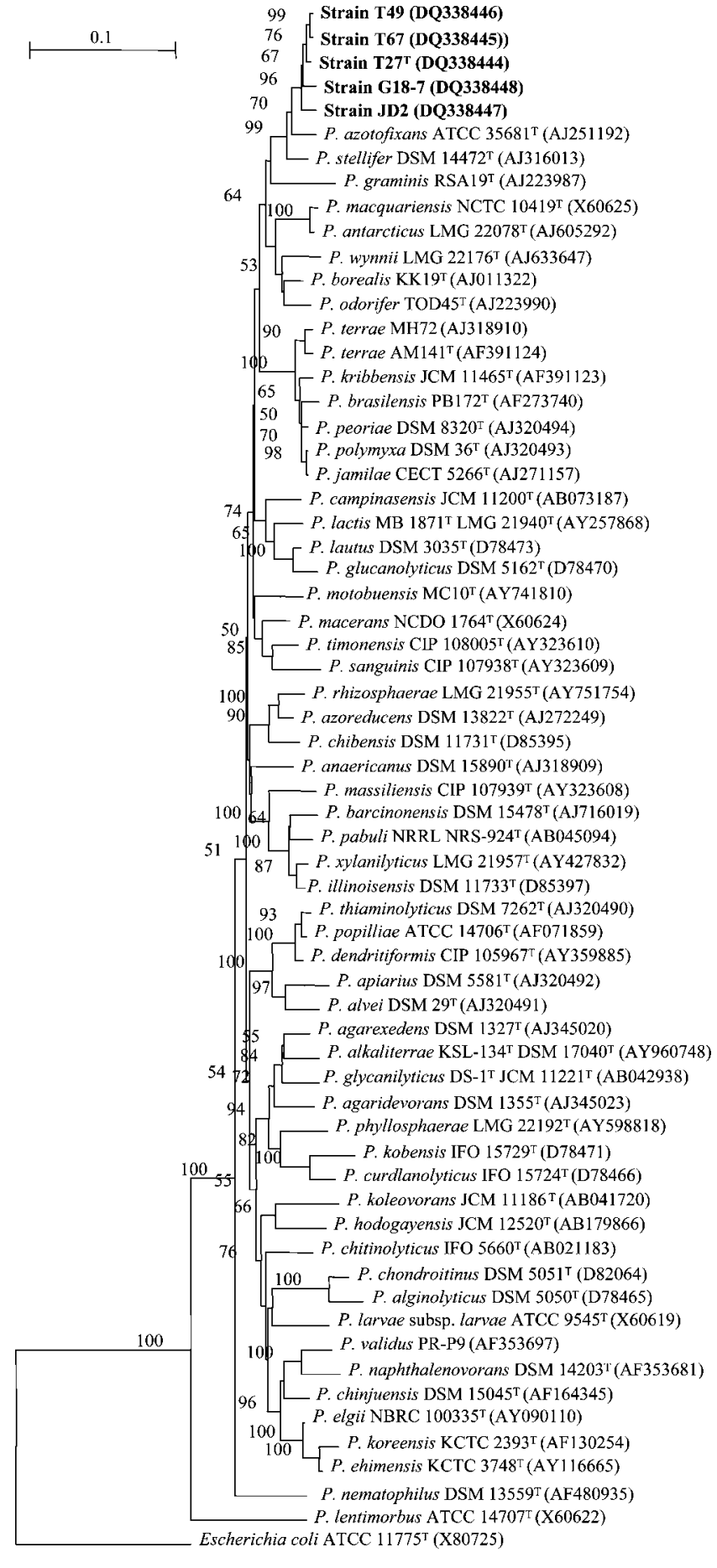

Fig. 2. Neighbour-joining tree, based on 16S rRNA gene sequences, showing the phylogenetic position of the five novel strains with respect to Paenibacillus species. Escherichia coli was used as an outgroup. Numbers at branching points represent bootstrap values from 1000 replicates; only values greater than $50 \%$ are shown. Bar, 0.1 substitutions per nucleotide position.

To determine the cellular morphology, the five bacterial strains were grown on endospore-forming medium [yeast extract (Oxoid), $0.07 \%$; tryptone (Oxoid), $0.1 \%$; glucose,
$0.1 \% ;\left(\mathrm{NH}_{4}\right)_{2} \mathrm{SO}_{4}, 0.02 \% ; \mathrm{MgSO}_{4} .7 \mathrm{H}_{2} \mathrm{O}, 0.02 \% ; \mathrm{K}_{2} \mathrm{HPO}_{4}$, $0.1 \%$; $\mathrm{pH} 7.2$ ] for $72 \mathrm{~h}$ and then the cells were examined by phase-contrast microscopy. The cells were found to be Gram-positive, aerobic, motile and rod-shaped $(0.7-0.8 \times 2.7-3.2 \mu \mathrm{m})$, and they produced ellipsoidal or oval spores located subterminally or centrally in swollen sporangia. The colonies of the strains on nutrient agar were circular, convex and glossy with entire margins.

Physiological and biochemical tests were performed using conventional methods. Catalase activity was analysed by bubble formation in a $3 \%(\mathrm{v} / \mathrm{v}) \mathrm{H}_{2} \mathrm{O}_{2}$ solution. The hydrolysis of casein, gelatin and starch was determined as described by Cowan \& Steel (1965). The utilization of various substrates as carbon and energy sources was determined as described by Shirling \& Gottlieb (1966). Tolerance of $\mathrm{NaCl}$ was measured in a medium $[0.5 \%$ peptone (Oxoid), $0.3 \%$ beef extract (Oxoid)] containing $\mathrm{NaCl}$ at concentrations of 3 and $5 \%(\mathrm{w} / \mathrm{v})$. Other physiological and biochemical tests were also determined using conventional methods. The phenotypic characteristics of the novel strains and several known nitrogen-fixing Paenibacillus species are presented in Table 2. A significant feature that differentiated the isolates from $P$. azotofixans and other Paenibacillus species was that none of the novel strains produced acid and gas from the following various carbohydrates: glucose, sucrose, lactose, fructose, glycerol, D-xylose, maltose, D-sorbitol, sodium succinate, sodium citrate, glycine and L-aspartate.

DNA $G+C$ contents were determined using the thermal melting protocol (De Ley et al., 1970): the values for the novel strains varied from 51.9 to $52.9 \mathrm{~mol} \%$. These values fell within the range for known Paenibacillus species (Shida et al., 1997), suggesting that the novel strains belong to that genus.

The levels of DNA-DNA hybridization were determined using the initial renaturation-rate method (De Ley et al., 1970): all of the novel strains displayed 12.9-29.5\% DNADNA relatedness to $P$. azotofixans. The level of DNA-DNA relatedness varied from 82.6 to $96.0 \%$ among the five novel strains. The results indicate that none of these novel strains is related to any known species of Paenibacillus and that they all belong to the same novel species.

Analysis of the cellular fatty acid compositions was carried out as described by Komagata \& Suzuki (1987), using the Sherlock Identification System (MIDI). The major fatty acid composition of strain $\mathrm{T} 27^{\mathrm{T}}$ is shown in Table 3 together with those of closely related Paenibacillus species. Anteisobranched $\mathrm{C}_{15: 0}$, the major fatty acid in members of the genus Paenibacillus, was also the major fatty acid component $(36.59 \%)$ of strain $\mathrm{T} 27^{\mathrm{T}}$.

In conclusion, on the basis of the phenotypic properties, $16 \mathrm{~S}$ rRNA gene sequences, $\mathrm{G}+\mathrm{C}$ contents, levels of DNADNA hybridization, chemotaxonomic properties and nifH sequences, the five novel strains form a very homogeneous 
Table 2. Characteristics of $P$. sabinae sp. nov. and closely related Paenibacillus species

Taxa: 1, P. sabinae (strains T27 ${ }^{\mathrm{T}}$, T49, T67, JD2 and G18-7); 2, P. azotofixans ATCC $35681^{\mathrm{T}} ; 3$, P. polymyxa DSM 36 ${ }^{\mathrm{T}}$; 4 , P. macerans ATCC $8244^{\mathrm{T}} ; 5$, P. odorifer TOD $45^{\mathrm{T}} ; 6$, P. graminis RSA19 $;$ 7, P. wynnii LMG $22176^{\mathrm{T}} ; 8$, Paenibacillus stellifer DSM $14472^{\mathrm{T}}$; 9 , P. brasilensis DSM $14914^{\mathrm{T}} ; 10$, P. peoriae IFO $15541^{\mathrm{T}}$. All show anaerobic growth. +, Positive reaction; - , negative reaction; V, variable reaction; ND, not determined.

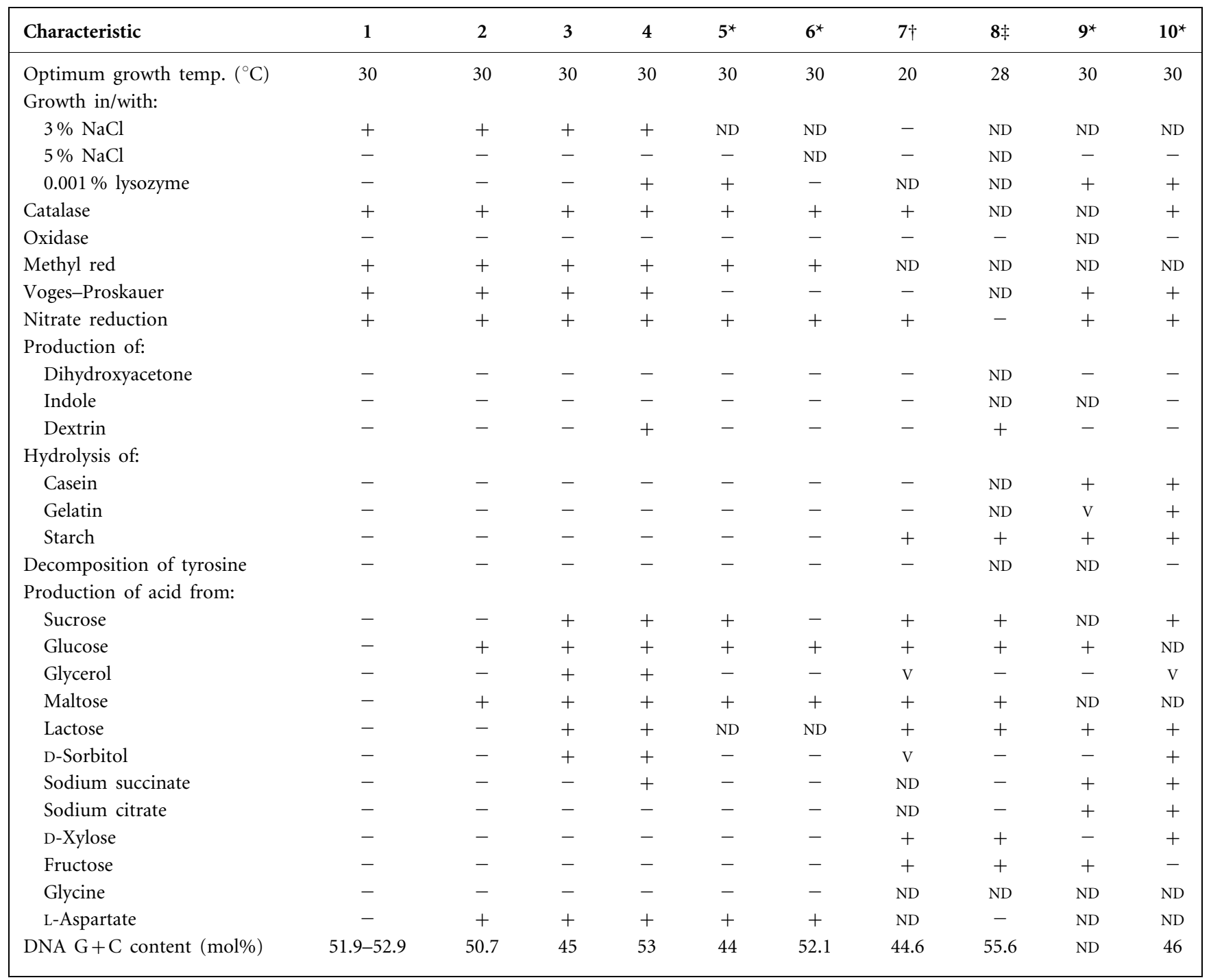

${ }^{*}$ Data from von der Weid et al. (2002).

$\dagger$ Data from Rodríguez-Díaz et al. (2005).

‡Data from Suominen et al. (2003).

group that is distinct from other related species within the genus Paenibacillus. Therefore, we propose that they represent a novel species of the genus Paenibacillus, for which the name Paenibacillus sabinae sp. nov. is proposed.

\section{Description of Paenibacillus sabinae sp. nov.}

Paenibacillus sabinae (sa'bi.nae. N.L. gen. n. sabinae of Sabina, referring to the plant Sabina squamata, the source of the rhizosphere soil from which the type strain was isolated).
Cells are Gram-positive, aerobic, motile, straight rods $(0.7-0.8 \times 2.7-3.2 \mu \mathrm{m})$. Oval or ellipsoidal endospores are produced, located subterminally or centrally in swollen sporangia. Colonies on nutrient agar are circular, convex and glossy with entire margins. The temperature range for growth is $4-37^{\circ} \mathrm{C}$ (optimum, $30^{\circ} \mathrm{C}$ ). Grows at $\mathrm{pH} 4.2-10.0$ (optimum, $\mathrm{pH}$ 7.2). Grows in $3 \%(\mathrm{w} / \mathrm{v}) \mathrm{NaCl}$, but does not tolerate $\mathrm{NaCl}$ at $5 \%(\mathrm{w} / \mathrm{v})$. Does not grow in $0.001 \%(\mathrm{w} / \mathrm{v})$ lysozyme. Catalase-positive and oxidase-negative. VogesProskauer and methyl red reactions are positive. Nitrate is 
Table 3. Cellular fatty acid profiles (\%) of $P$. sabinae sp. nov. $127^{\top}$ and closely related Paenibacillus species

Strains: 1, strain $\mathrm{T} 27^{\mathrm{T}}$; 2, P. azotofixans ATCC $35681^{\mathrm{T}}$ (data from Yoon et al., 2003); 3, P. stellifer DSM $14472^{\mathrm{T}}$ (Suominen et al., 2003); 4, P. polymyxa DSM 36 ${ }^{\mathrm{T}}$ (Yoon et al., 2003); 5, P. macerans ATCC $8244^{\mathrm{T}}$ (Elo et al., 2001). NR, Not reported.

\begin{tabular}{|lrrrrr|}
\hline Fatty acid & $\mathbf{1}$ & $\mathbf{2}$ & $\mathbf{3}$ & $\mathbf{4}$ & $\mathbf{5}$ \\
\hline Saturated straight-chain & & & & & \\
$\mathrm{C}_{14: 0}$ & 2.96 & 5.0 & 0.7 & 5.0 & 3.7 \\
$\mathrm{C}_{15: 0}$ & 1.54 & 2.2 & 0.5 & 3.4 & 0.5 \\
$\mathrm{C}_{16: 0}$ & 18.19 & 15.5 & 9.1 & 20.5 & 17.9 \\
$\mathrm{C}_{17: 0}$ & 0.71 & $\mathrm{NR}$ & $\mathrm{NR}$ & $\mathrm{NR}$ & $\mathrm{NR}$ \\
$\mathrm{C}_{18: 0}$ & 3.28 & 0.3 & 1.1 & 0.3 & $\mathrm{NR}$ \\
Saturated iso-branched & & & & & \\
$\mathrm{C}_{13: 0} 3-\mathrm{OH}$ & 1.39 & $\mathrm{NR}$ & $\mathrm{NR}$ & $\mathrm{NR}$ & $\mathrm{NR}$ \\
$\mathrm{C}_{14: 0}$ & 3.20 & 4.7 & 0.6 & 4.7 & 1.8 \\
$\mathrm{C}_{15: 0}$ & 1.37 & 8.7 & 5.5 & 8.7 & 2.6 \\
$\mathrm{C}_{15: 1} \mathrm{I}$ & 0.71 & $\mathrm{NR}$ & $\mathrm{NR}$ & $\mathrm{NR}$ & $\mathrm{NR}$ \\
$\mathrm{C}_{16: 0}$ & 14.40 & 5.3 & 7.7 & $\mathrm{NR}$ & 17.1 \\
$\mathrm{C}_{17: 0}$ & 0.79 & 1.1 & 7.0 & $\mathrm{NR}$ & 4.1 \\
Saturated anteiso-branched & & & & & \\
$\mathrm{C}_{15: 0}$ & 36.59 & 45.4 & 49.9 & 45.5 & 34.5 \\
$\mathrm{C}_{17: 0}$ & 6.38 & 2.1 & 16.7 & 2.1 & 16.1 \\
Unsaturated $^{\star}$ & & & & & \\
$\mathrm{C}_{16: 1} \omega 7 c$ & 1.78 & $\mathrm{NR}$ & $\mathrm{NR}$ & $\mathrm{NR}$ & $\mathrm{NR}$ \\
$\mathrm{C}_{18: 1} \omega 7 c$ & 1.22 & $\mathrm{NR}$ & $\mathrm{NR}$ & $\mathrm{NR}$ & $\mathrm{NR}$ \\
$\mathrm{C}_{18: 1} \omega 9 c$ & 3.88 & $<0.2$ & $<0.2$ & $<0.2$ & $<0.2$ \\
\hline
\end{tabular}

*The position of the double bond can be located by counting from the methyl $(\omega)$ end of the carbon chain. A cis isomer is indicated by the suffix $c$.

reduced to nitrite. Nitrogen fixation is detected by acetylene reduction and from the presence of the nifH gene. Acid and gas are not produced from the following carbohydrates: glucose, sucrose, lactose, fructose, glycerol, D-xylose, maltose, D-sorbitol, sodium succinate, sodium citrate, glycine and L-aspartate. Gelatin, casein and starch are not hydrolysed. The major cellular fatty acids are anteiso- $\mathrm{C}_{15: 0}$, iso- $\mathrm{C}_{16: 0}$ and $\mathrm{C}_{16: 0}$.

The DNA G + C content of the type strain is $51.9 \%$. The type strain, $\mathrm{T} 27^{\mathrm{T}}\left(=\mathrm{CCBAU} 10202^{\mathrm{T}}=\mathrm{DSM} 17841^{\mathrm{T}}\right)$, was isolated from the rhizosphere soil of Sabina squamata planted in Beijing, China.

\section{Acknowledgements}

We are grateful to Dr Berge for the generous gifts of $P$. polymyxa and $P$. macerans strains. We thank Professor Tianshen Tao of the Chinese Academy of Agricultural Sciences. This work was supported by the Chinese National '973' Project (grant no. 001CB108904).

\section{References}

Ash, C., Priest, F. G. \& Collins, M. D. (1993). Molecular identification of rRNA group 3 bacilli (Ash, Farrow, Wallbanks and Collins) using a PCR probe test. Proposal for the creation of a new genus Paenibacillus. Antonie van Leeuwenhoek 64, 253-260.

Berge, O., Guinebretière, M. H., Achouak, W., Normand, P. \& Heulin, T. (2002). Paenibacillus graminis sp. nov. and Paenibacillus odorifer sp. nov., isolated from plant roots, soil and food. Int J Syst Evol Microbiol 52, 607-616.

Cowan, S. T. \& Steel, K. J. (1965). Manual for the Identification of Medical Bacteria. London: Cambridge University Press.

De Ley, J., Cattoir, H. \& Reynaerts, A. (1970). The quantitative measurement of DNA hybridization from renaturation rates. Eur $J$ Biochem 12, 133-142.

Ding, Y., Wang, J., Liu, Y. \& Chen, S. (2005). Isolation and identification of nitrogen-fixing bacilli from plant rhizospheres in Beijing region. J Appl Microbiol 99, 1271-1281.

Elo, S., Suominen, I., Kämpfer, P., Juhanoja, J., Salkinoja-Salonen, M. \& Haahtela, K. (2001). Paenibacillus borealis sp. nov., a nitrogenfixing species isolated from spruce forest humus in Finland. Int J Syst Evol Microbiol 51, 535-545.

Grau, F. H. \& Wilson, P. W. (1962). Physiology of nitrogen fixation by Bacillus polymyxa. J Bacteriol 83, 490-496.

Komagata, K. \& Suzuki, K. (1987). Lipid and cell-wall analysis in bacterial systematics. Methods Microbiol 19, 161-207.

Rodriguez-Díaz, M., Lebbe, L., Rodelas, B., Heyrman, J., De Vos, P. \& Logan, N. A. (2005). Paenibacillus wynnii sp. nov., a novel species harbouring the nifH gene, isolated from Alexander Island, Antarctica. Int J Syst Evol Microbiol 55, 2093-2099.

Seldin, L., van Elsas, J. D. \& Penido, E. G. C. (1983). Bacillus azotofixans from Brazilian soils. Plant Soil 70, 243-255.

Seldin, L., van Elsas, J. D. \& Penido, E. G. C. (1984). Bacillus azotofixans sp. nov., a nitrogen-fixing species from Brazilian soils and grass roots. Int J Syst Bacteriol 34, 451-456.

Shida, O., Takagi, H., Kadowaki, K., Nakamura, L. K. \& Komagata, K. (1997). Transfer of Bacillus alginolyticus, Bacillus chondroitinus, Bacillus curdlanolyticus, Bacillus glucanolyticus, Bacillus kobensis, and Bacillus thiaminolyticus to the genus Paenibacillus and emended description of the genus Paenibacillus. Int J Syst Bacteriol 47, 289-298.

Shirling, E. B. \& Gottlieb, D. (1966). Methods for characterization of Streptomyces species. Int J Syst Bacteriol 16, 313-340.

Suominen, I., Spröer, C., Kämpfer, P., Rainey, F. A., Lounatmaa, K. \& Salkinoja-Salonen, M. (2003). Paenibacillus stellifer sp. nov., a cyclodextrin-producing species isolated from paperboard. Int J Syst Evol Microbiol 53, 1369-1374.

Tcherpakov, M., Ben-Jacob, E. \& Gutnick, D. L. (1999). Paenibacillus dendritiformis sp. nov., proposal for a new pattern-forming species and its localization within a phylogenetic cluster. Int J Syst Bacteriol 49, 239-246.

Thompson, J. D., Higgins, D. G. \& Gibson, T. J. (1994). CLUSTAL W: improving the sensitivity of progressive multiple sequence alignment through sequence weighting, position-specific gap penalties and weight matrix choice. Nucleic Acids Res 22, 4673-4680.

Thompson, J. D., Gibson, T. J., Plewniak, F., Jeanmougin, F. \& Higgins, D. G. (1997). The CLUSTAL_X windows interface: flexible strategies for multiple sequence alignment aided by quality analysis tools. Nucleic Acids Res 25, 4876-4882.

Van der Maarel, M. J., Veen, A. \& Wijbenga, D. J. (2000). Paenibacillus granivorans sp. nov., a new Paenibacillus species which degrades native potato starch granules. Syst Appl Microbiol 23, 344-348. 
Van de Peer, Y. \& De Wachter, R. (1994). TREECON for Windows: a software package for the construction and drawing of evolutionary trees for the Microsoft Windows environment. Comput Appl Biosci 10, 569-570.

von der Weid, I., Duarte, G. F., van Elsas, J. D. \& Seldin, L. (2002). Paenibacillus brasilensis sp. nov., a novel nitrogen-fixing species isolated from the maize rhizosphere in Brazil. Int $J$ Syst Evol Microbiol 52, 2147-2153.

Weaver, P. F., Wall, J. D. \& Gest, H. (1975). Characterization of Rhodopseudomonas capsulata. Arch Microbiol 105, 207-216.
Witz, D. F., Detroy, R. W. \& Wilson, P. W. (1967). Nitrogen fixation by growing cells and cell-free extracts of the Bacillaceae. Arch Mikrobiol 55, 369-381.

Yoon, J.-H., Lee, K.-C., Kang, S.-S., Kho, Y. H., Kang, K. H. \& Park, Y.-H. (2002). Janibacter terrae sp. nov., a bacterium isolated from soil around a wastewater treatment plant. Int J Syst Evol Microbiol 50, 1821-1827.

Yoon, J.-H., Oh, H.-M., Yoon, B.-D., Kang, K.-H. \& Park, Y.-H. (2003). Paenibacillus kribbensis sp. nov. and Paenibacillus terrae sp. nov., bioflocculants for efficient harvesting of algal cells. Int J Syst Evol Microbiol 53, 295-301. 